\title{
Publisher Correction to: BMC Rheumatology, volume 3
}

BMC Rheumatology

\section{Publisher Correction to: BMC Rheumatology, volume 3}

An error occurred during the publication of a number of articles in BMC Rheumatology. Several articles were published in volume 3 with a duplicate citation number.

In this correction article the old and new citation metadata are published in Table 1 .

Table 1 Overview of incorrect and correct citation metadata

\begin{tabular}{lll}
\hline DOI & $\begin{array}{l}\text { Incorrect } \\
\text { citation number }\end{array}$ & $\begin{array}{l}\text { Correct } \\
\text { citation number }\end{array}$ \\
\hline $10.1186 /$ s41927-019-0067-6 & 1 & 23 \\
$10.1186 /$ s41927-019-0069-4 & 4 & 20 \\
$10.1186 /$ s41927-019-0070-y & 2 & 24 \\
$10.1186 /$ s41927-019-0071-x & 3 & 22 \\
$10.1186 /$ s41927-019-0072-9 & 5 & 21 \\
\hline
\end{tabular}

The original articles have been updated. The publisher apologizes for the inconvenience caused to our authors and readers.

Published online: 20 August 2019

\footnotetext{
* Correspondence: info@biomedcentral.com

London, UK
} 